\title{
Examining Challenges Leading to Low Integration of Savings and Credit Co-Operative Societies (SACCOs) in National Economies: A Study of Zambia
}

\author{
Matongo Chikuba Shilimi \\ Eastern and Southern African Trade and Development Bank (TDB), Nairobi, Kenya \\ Email: ncmatongo@gmail.com
}

How to cite this paper: Shilimi, M. C. (2021). Examining Challenges Leading to Low Integration of Savings and Credit Co-Operative Societies (SACCOs) in National Economies: A Study of Zambia. Open Journal of Business and Management, 9, 1338-1366. https://doi.org/10.4236/ojbm.2021.93073

Received: March 26, 2021

Accepted: May 28, 2021

Published: May 31, 2021

Copyright (อ 2021 by author(s) and Scientific Research Publishing Inc. This work is licensed under the Creative Commons Attribution International License (CC BY 4.0).

http://creativecommons.org/licenses/by/4.0/ (c) (i) Open Access

\begin{abstract}
Savings and Credit Co-operative Societies (SACCOs) contribute significantly towards economically empowering people and easing poverty owing to their member-driven structure in ownership, management, mobilising resources and advancing low-cost credit without need for external collateral. In Zambia, SACCOs integration is low, hence the impetus for this research. The target population included adult-age Zambians and the sample was derived using multistage and simple random sampling techniques. Adopting a quantitative approach, data was gathered using a questionnaire. ANOVA tests on the statistical significance between the independent and dependent variables were $F(8,269)=505.92, p<0.05$. Research findings reveal strong, positive relationship between the use of SACCOs and awareness education, financial literacy, societal influence, governance, and government regulation, while the use of SACCOs and income had a significantly negative correlation. The correlation between age and gender and use of SACCOs was not significant. The study recommends that the government takes strategic leadership in reviving the SACCO sector through awareness education and enacting enforceable legislation to govern SACCOs. Communities should be empowered to drive the integration process and employers encouraged to adopt SACCOs in their organizational strategies given the SACCOs' national impact and strategic role.
\end{abstract}

\section{Keywords}

SACCO, Co-Operative, Zambia, Economic-Empowerment, Poverty-Alleviation, Financial Literacy, Government Regulation, Governance, Income 


\section{Introduction}

\subsection{Overview}

The notion of people cooperating and working together for the economic and social development of society has existed throughout human history. Present day co-operative societies are many and varied, serving different goals and objectives of members. The International Co-operative Alliance (ICA) describes a co-operative as "an autonomous association of persons united voluntarily to meet their common economic, social, and cultural needs and aspirations through a jointly-owned and democratically-controlled enterprise" (ICA, 2018).

A Savings and Credit Co-operative Society (SACCO) is a voluntary membership financial organization that members own, run, and manage, with an objective of empowering members through mobilising and pooling resources, and providing credit to members (Waweru, 2011). Thus, users of SACCO service are the same people who own, finance, manage and control them, and ultimately derive equitable benefits from their use. Members are usually drawn from a place of common bond, including workplace, profession, and domicile, among others. Therefore, the underlying importance of SACCOs is in their means for economic empowerment and alleviation of poverty through member contribution, pooling of savings, and access to credit. The World Bank has identified economic empowerment as a crucial strategic constituent for poverty reduction and development of any country (World Bank, 2018).

\subsection{Research Problem}

In 2018, the population of Zambia was estimated at 17.1 million people and of these, $67 \%$ were considered moderately poor, living on less than US $\$ 3.10$ a day according to the United Nations Development Programme (UNDP, 2018). This is largely due to lack of access to credit, as close to $40.7 \%$ of the population experience financial exclusion (FinScope, 2015). The situation is exacerbated by the soaring costs of borrowing, inability to raise collateral, and absence of financial institutions in rural areas where the population is concentrated. Despite their apparent role in economic empowerment and poverty alleviation, as well as being community-based, SACCOs are not popular in Zambia. According to statistics from the World Council of Credit Unions (WOCCU, 2018), Zambia ranks among the lowest in Africa with 1197 credit unions worth US\$ 25.2 million in assets.

The purpose of this study is to investigate the factors that have impeded the high penetration of SACCOs in Zambia, with a view to consolidating practical recommendations to accelerate the presence of SACCOs for economic empowerment and poverty alleviation of the populace. Specifically, the study will attempt to answer the questions:

1) What are the challenges that have contributed to the low integration of SACCOs in Zambia? 
2) What factors influence the level of use of SACCOs?

Previous studies in Zambia have dwelt on performance and relevance of microfinance institutions and co-operatives in general, with hardly any evidence of research on SACCOs and especially on their apparent low presence despite SACCOs' strategic role of economically empowering societies (Lolojih, 2009; FinMark Trust, 2013; Agri-ProFocus Zambia, 2014; FinScope, 2015). Existing studies on SACCOs were done outside Zambia and may not necessarily address the country's unique issues. The identified research problem and research gap make this study significant.

\subsection{Co-Operative Societies Global Overview}

The foundation of the Rochdale Society of Equitable Pioneers in 1844 in England is widely acknowledged as the origin of formal co-operatives. In a bid to ease the hardships brought on by the industrial revolution, the Rochdale Pioneers worked jointly and adopted principles which guided their operations as a co-operative society (Mayo, 2017). This co-operative movement spread globally over time, culminating into the formation of the International Co-operative Alliance (ICA), founded in 1895 as the global federation of co-operatives. ICA has its own distinct identity, history, structure, and purpose and transcends a wide range of economic activities in agriculture, credit and banking, insurance, retailing, wholesaling, industry, and commerce, with over 1 billion members, employing around 250 million people around the world (ICA, 2018).

\subsection{Global Overview of SACCOs}

The origin of SACCOs can be traced to Europe when Herman Schulze and William Raiffersen pioneered the first SACCO in Germany in 1849, necessitated by a need to help people facing economic hardship due to crop failure and famine in the region (McKillop \& Wilson, 2011). According to the authors, in England, SACCOs emerged in 1850 when mill factory workers organized themselves to save and extend credit to each other. In Spain, the Mondragon Co-operatives started by a Catholic priest in 1943 to assist disadvantaged youth spurred SACCO formation. The co-operative acquired its own Bank in 1959 and became one of the largest enterprises in Spain (Lopez, Lopez, \& Larraga, 2009). As people continued moving from Europe during the twentieth century, SACCOs extended to North America, and subsequently to other parts of the world.

The growth of SACCOs globally precipitated the formation of the World Council of Credit Unions (WOCCU) in 1970. The mandate of WOCCU is to ensure that there is financial inclusion of all people through credit societies, and to provide a platform for members to network, seek assistance, and access training, with a view to promoting the cause of the global credit movement of accessibility to affordable, reliable, and sustainable financial services for all people (WOCCU, 2018). In Africa, SACCOs were first introduced in Ghana in 1959 and spread to other English-speaking nations first, particularly Uganda, Nigeria, 
Tanzania, and Kenya (Mwakajumilo, 2011). The non-English speaking countries adopted SACCOs in the 1960s, with major incursion in the 1970s. The influx of SACCOs led to the formation of the African Confederation of Co-Operative Savings and Credit Associations (ACCOSCA) in 1968. The primary objective of ACCOSCA is to empower the savings and co-operative societies in the continent through capacity building, financial and technical assistance, research, information exchange and establishment of an institutional framework that promotes savings mobilization and availing of credit (ACCOSCA, 2018).

\subsection{Evolution of Co-Operatives in Zambia}

The history of co-operatives in Zambia goes as far back as 1914 when European farmers formed co-operatives particularly for marketing their agricultural produce (Lolojih, 2009). Overtime, co-operatives spread to the indigenous Zambian community, and were endorsed as mass economic empowerment organizations under the country's Chifubu declaration of 1969. Consequently, the Ministry of Co-operatives was created whose mandate was to administer the operations of co-operative societies. Co-operatives flourished thereon, creating employment at grass-root, district, and provincial levels, and were rated as the third largest employer in the country (Lolojih, 2009). Co-operatives evolved from agricultural-focused entities to other sectors of the economy such as transportation, insurance, and micro-finance.

In 1991, Zambia first underwent a change in the ruling regime and secondly, the country emerged from a single party state and embraced multi-party democracy. The change impacted the co-operatives which were viewed as state entities when the new government embarked on policies that saw state entities being privatized and the economy being liberalized. With government sponsorship withdrawn, many co-operatives collapsed. In addition, the Ministry of Co-operatives was abolished in 1991, and its functions moved to the Ministry of Agriculture as a section in the Food Security Division. This resulted into a weak co-operative movement in Zambia, which has continued to date. However, with the government's efforts to revive the co-operative movement recently, the Department of Co-operatives was relocated to the Ministry of Commerce and Industry in 2016, where it is currently residing.

\section{Literature Review}

\subsection{Theoretical Framework}

The theoretical framework examines theories and concepts in the broader field of study that gives insight into people's decisions to save, manage their finances and improve their economic welfare.

\subsubsection{Lifecycle of Savings}

Developed by Modigliani and Brumberg (1954), the Lifecycle of Saving theory advances that people save more when they are young, and as they near retire- 
ment, savings diminish because of increase in age-related expenditure. The savings are typically low in the early $20 \mathrm{~s}$ of one's age, peaking in middle ages of around 40 years, before steadily declining from around age 50 through retirement years and beyond. Net savings are typically between ages 25 and 65, while before and after is usually a dis-saving phase (Pettinger, 2017). This savings pattern as described by Pettinger, 2017 as depicted in Figure 1.

A fundamental assumption of the theory is that households' savings behaviours will be informed by current and future consumption expectations. Aggregate savings should occur if there is no bequest motive and therefore the positive savings of the young offsets the negative savings of the old generation (Horioka, 2016; Banerjee, Meng, \& Qian, 2010). Furthermore, household savings are a function of average income and the age composition of a population. As the young dependency ratio increases, savings rates will also decline but when population growth is static and age distribution is balanced, savings are evened out (Issahaku, 2011).

\subsubsection{Conceptual Model of Financial Literacy}

Advanced by Hung, Parker, and Yoong (2009), the Model of Financial Literacy introduces four facets of financial literacy which determine individuals' financial behaviours and the linkages between them. It asserts that there is a link between an individual's actual tacit or demonstrated basic financial knowledge, their financial skills, and competencies, their perceived and explicitly exhibited knowledge, and the resultant financial behaviour arising out of the financial knowledge and skills. The individual's financial behaviour is the sum-total of interaction between actual knowledge, perceived knowledge, and financial skills. Therefore, the more financially knowledgeable a person is, the sharper their financial skills and consequently, their ability to make better savings and economic decisions.

Figure 2 shows the Model of Financial Literacy.

\subsubsection{Friedman's Permanent Income Hypothesis}

The theory propagated by Friedman (1957), suggests that what determines

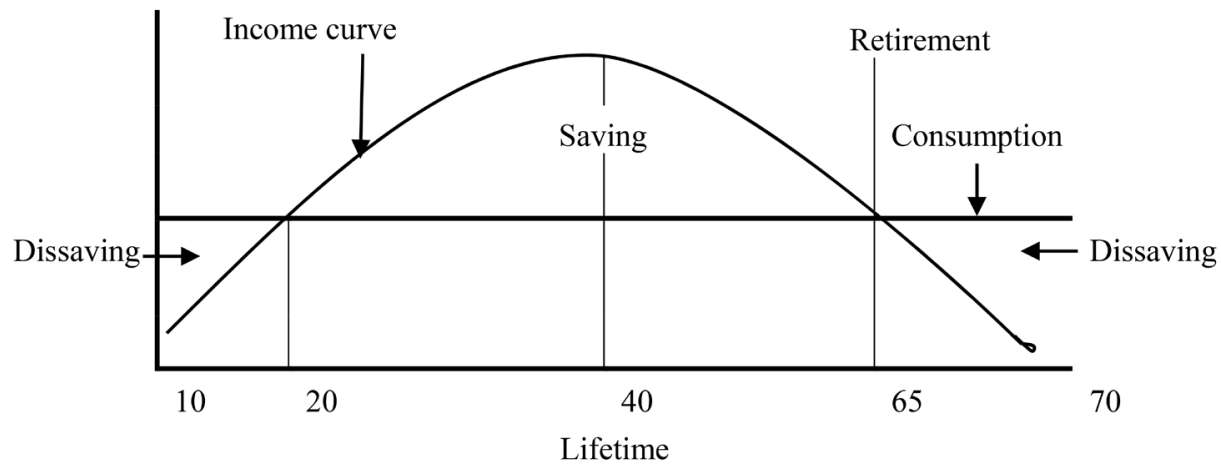

Source: https://www.economicshelp.org/blog/27080/concepts/life-cycle-hypothesis/.

Figure 1. Life-cycle model. 


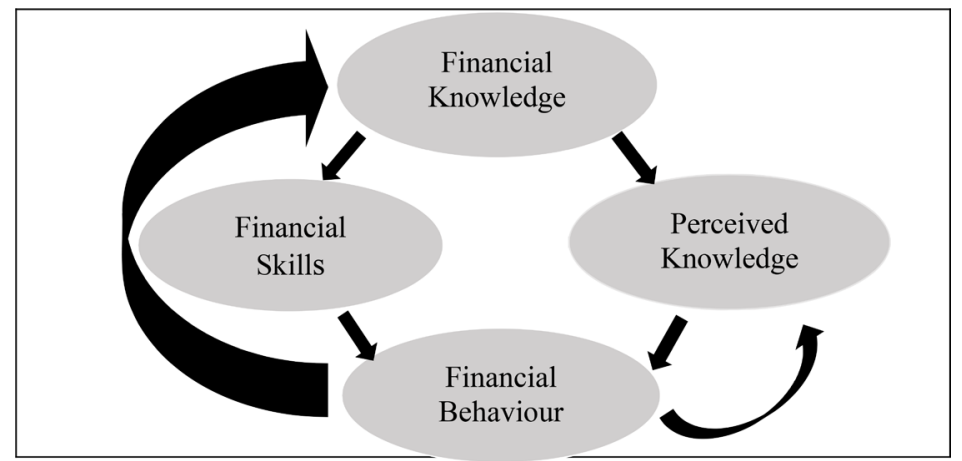

Source: Hung, Parker, and Yoong (2009: p. 12).

Figure 2. Conceptual model of financial literacy.

household consumption is long-term income. As per permanent income hypothesis theory, there are two distinct types of income that determine household savings, namely permanent income, and transitory income. Permanent income is the average income, which people expect to get in every period in the future at their present wealth level while transitory income is the variance between actual and permanent income (Altunc \& Aydin, 2014). Households do not utilise transitory income for consumption but rather, channel it into savings.

Put in a simple linear equation,

$$
Y=Y_{p}+Y_{t}
$$

where:

$Y=$ Measured income or income actually received.

$Y_{p}=$ Permanent Income.

$Y_{t}=$ Transitory Income.

In his conclusions, Friedman (1957), assumes that there is no correlation between $Y_{p}$ and $Y_{t}$, and therefore it follows that a high permanent income is not correlated with a high transitory income and vice-versa. Hence, transitory income determines the level and frequency of savings in a household.

\subsubsection{Social Psychology Theory}

A psychological theory describes current behaviour and predicts future behaviours (Chung-Yan, Krieger, \& Towson, 2017). The theory that closely underpins modern day psychological thinking is that of Allport (1924), who introduced the notion that the presence of others can facilitate certain behaviours among members of a social group. Bandura, Ross and Ross (1963), developed the concept that behaviour in a social world could be modelled as individuals were likely to copy the behaviours of those, they considered superior to them. Likewise, the Minimal Group Paradigm, a theory on social identity by Tajfel, Billig, Bundy and Flament (1971), asserts that individuals tended to maintain strong allegiance to their group, viewing it as a positive sense of social and personal belonging. Thus, apart from an individual's own conscious decisions, influences from family, peers, and society impact people's behaviours including financial decisions. 


\subsubsection{Institutional Theory of Savings}

As postulated in earlier literature by Sherraden (1991), the theory amplifies the vital role that structured arrangements play in savings behaviours and patterns. The theory views the individuals' behaviour as shaped by the influence of the surrounding environment represented by institutions consisting of rules, regulations, opinions, and social values. Institutional theory of savings posits that as social structures, values, rules, and norms are inculcated in an institution, they become the acceptable authority that guides society's social behaviour (Curley, Ssewamala, \& Sherraden, 2009), thus incorporating human savings behaviour into a structured and formalized system.

The institutional theory of savings presents five paradigms that are instrumental in shaping an individual's savings and wealth growth, especially among low-income households: access, information, incentives, facilitation, and expectations (Curley et al., 2009). The authors argue that although important, individual attributes and income alone cannot fully explain the saving behavour of individuals. The main hypothesis of institutional theory advances that it is the expectation of society that low-level income families are not able to save or accumulate wealth as their more affluent counterparts because they are not exposed to the same institutional opportunities (Curley et al., 2009).

\subsubsection{Agency Theory}

Agency theory is premised on the agency relationships that exist in organizations. An agency relationship is said to exist where one party, the principal, engages another, the agent, to act on their behalf, with some degree of delegated decision-making authority (Chaddad \& Valentinov, 2016). The focal point of agency theory is the probable divergent self-interests of the two parties leading to problems in the principal-agent relationship. The principal expects the agent's actions and decisions to be in the principal's interest but the agent on his part may not necessarily or willingly act in the best interest of the principal (Haslinda \& Valentine, 2009). Therefore, aligning the interests of the agents and principals is a crucial component of the agency theory which calls for a trade-off between incentive and risk-sharing in the principal-agent contracts (Chaddad \& Valentinov, 2016; Haslinda \& Valentine, 2009).

Information asymmetry too necessitates agency costs. This arises when the agent possesses more information than the principal regarding the details of expected activities, his own actions, abilities, and preferences (Vera, Ugedo, \& Lario, 2010). With this information leverage and knowing the prohibitive monitoring costs of their activities and performance, agents often exploit this privileged position by engaging in opportunistic behaviours that are contrary to what principals expect thereby reducing the productivity of the entity.

\subsection{Empirical Review}

A conceptual framework is an abstract representation that is linked to the study 
object and is used to direct the collection and analysis of data (Shields \& Rangarajan, 2013). Based on the review of literature from the existing studies, a conceptual framework was developed to focus this study on specific variables. Factors that were identified as impacting people's financial behaviours and that informed the direction of this study include: Awareness education, financial literacy, societal influence, age, gender, level of income, corporate governance, and government regulation.

These variables are presented in the Conceptual Framework Figure 3.

\subsubsection{Awareness Education}

According to the American President's Advisory Council on Financial Literacy (2008), financial education is the process of gaining an understanding of financial products, services, and concepts, that empower individuals to make well-thought-out choices, avoid dangers, access assistance, and engage in any other behaviours that enhance their financial security currently and in the future. The benefits of financial education permeate through the entire society, reducing a nation's financial exclusion, increasing knowledge that is necessary for sound financial behaviours among the population, creating competitiveness

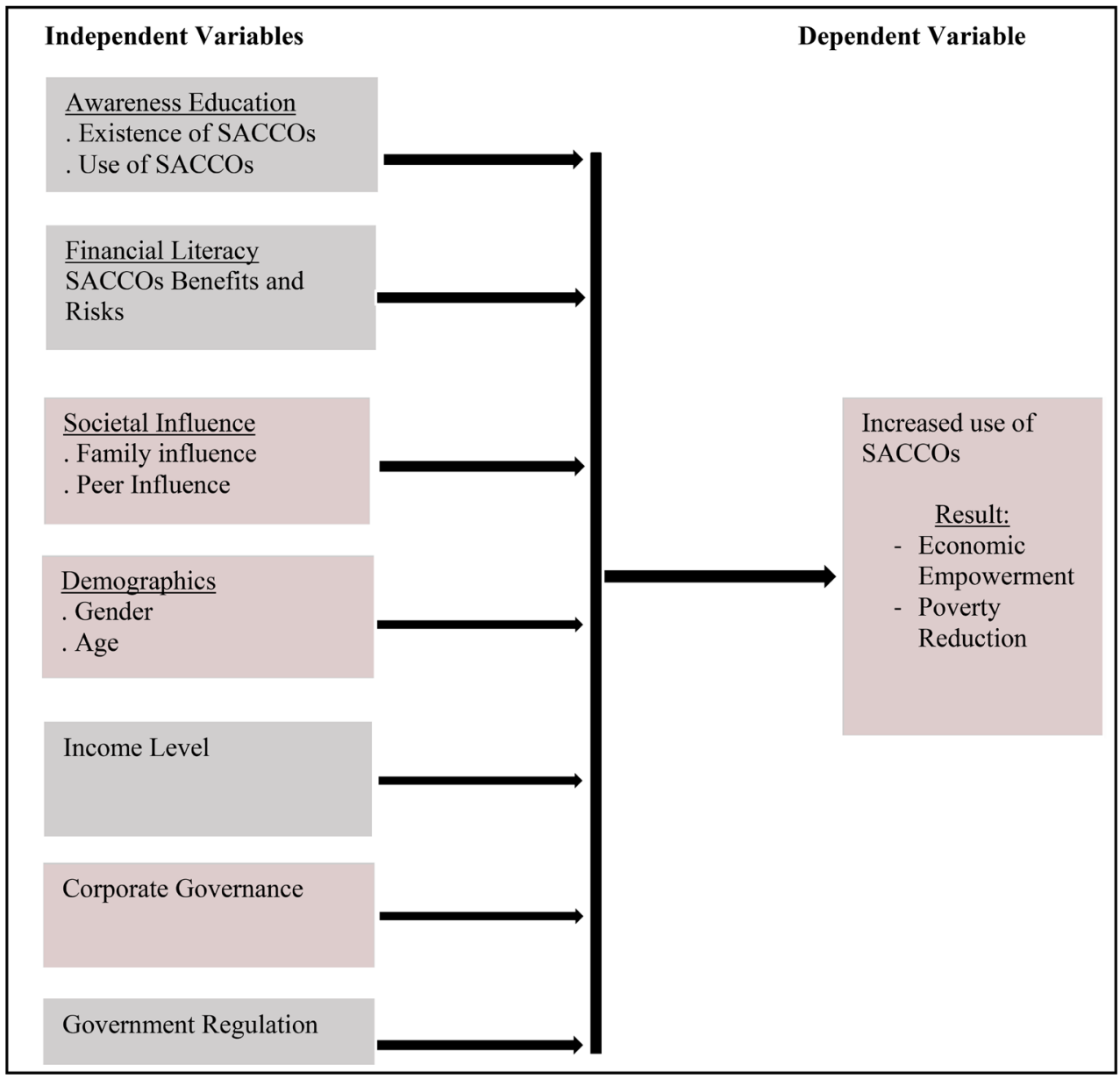

Figure 3. conceptual framework. 
as well as wealth and liquidity for the financial markets (Bertea \& Zait, 2014).

Recognizing the importance of financial education, the European parliament passed a resolution in 2008, to ensure that consumers were well educated and sensitized in financial matters especially credit (Bertea \& Zait, 2014). Likewise, empirical studies place awareness education among the top-most principal factors that determine individuals' savings decisions. People who had received financial education had increased savings (Lusardi \& Mitchell, 2014). Conversely, lack of access to relevant personal financial knowledge was a key deterrent to savings (Turnham, 2010) and resulted in higher debt and default in meeting consumer credit obligations (Gathergood, 2012). Lack of awareness of SACCOs and their benefits was found to hamper development of SACCOs alongside poor savings culture and prohibitive costs of borrowing (Kifle, 2012). Thus, as individuals become more informed about the options available for them to save, the more likely they are to engage in savings activities.

The co-operative movement recognises the importance of member education in shaping the growth and development of co-operatives worldwide, terming it the lifeblood of all co-operatives without which co-operatives would not develop. This is underscored in the fifth Co-operative Principle which emphasizes the centrality of the co-operative education, training and information in development, nature, and benefits of the co-operatives (ICA, 2018). The continued survival, effective management and viability of co-operatives depend on educating and training co-operative members and enhancing their knowledge of co-operative principles and members' rights (Adekola \& Dokubo, 2017).

\subsubsection{Financial Literacy}

Financial literacy is broadly the application of knowledge and skills by an individual that enables one to effectively manage their financial resources leading to a healthy financial status throughout their life (Lusardi \& Mitchell, 2014). Governments, policy makers, economists, academicians, and practitioners have increasingly paid attention to financial literacy (Harnisch, 2010). Thus, in the wake of sophisticated financial products and increasing customers' needs, financial literacy has become a fundamental necessity especially considering high and at times hidden costs, growing debt, and low savings levels (Lusardi \& Mitchell, 2014).

Several studies conducted on financial literacy and its effect on people's savings behaviour have concluded that financially literate individuals analysed the costs, risks, and benefits, and made better financial decisions (Nye, Pete, \& Cinnamon, 2013), and engaged more in savings and investments activities (Beckmann, 2013). Conversely, individuals who were not financially literate often made bad financial decisions and poor choices of investment (Lusardi \& Mitchell, 2014), were more likely to engage in costly debt (Mottola, 2013), were vulnerable to severe financial crises and had a high chance of financial exclusion (Wachira \& Kihiu, 2012). 


\subsubsection{Societal Influence}

Cultural orientations, family, and peer influences have been cited as playing a role in impacting people's savings behaviour (Otto, 2012; Webley \& Nyhus, 2012). Beliefs, preferences, and language have been found to influence savings behaviours in Asian societies (Chen, 2013). Studies have shown evidence of inter-generational transmission of savings patterns and attitudes influencing individuals' savings and financial decisions (Brown \& Taylor, 2016; Cronqvist \& Siegel, 2015). Research has indicated that individuals' financial behaviours are influenced by the decisions of peers (Karunaanithy, Karunanithy, \& Santhirasekaram, 2017; Lusardi, Mitchell, \& Curto, 2010). On the contrary, Horioka (2016) argued that the Japanese savings choice and behaviour was informed more by rational behaviour in the context of their socio-economic and policy environment rather than family or peer influence.

\subsubsection{Gender}

Although previous studies are conflicted in their findings on savings behaviours between men and women, findings are that generally the savings behaviours between the genders were different. Some research has revealed that on average, women had a lower risk tolerance and saved less than men (Majurin, 2012; Obayelu, 2012) while others concluded that women saved more than men (Bokemeiner, Loveridge, \& Whitaker, 2013; Mahdzan \& Tabiani, 2013).

\subsubsection{Age}

Literature on the impact of age on savings behaviour is very scanty. Nonetheless, in line with the Lifecycle of savings theory, studies have shown that there is a positive relationship between savings and age (Chowa, Masa, \& Ansong, 2012) with savings rising and peaking in middle age before declining in retirement age. Equally, Bover, Casado, Costa, DuCaju, McCarthy, Sierminska, Tzamourani, Villanueva, and Zavadil (2013) found that debt burden and negative savings were higher in early lifecycle years and reduced after the age of 44 .

\subsubsection{Income Level}

Extant literature has demonstrated that household savings are different across various income groups. Typically, savings were found to be low and erratic for households with low-income levels (Corporation for Enterprise Development, 2016; Hardy \& Ziliak, 2014) and especially for those headed by a single parent (Gjertson, 2016; DeNavas-Walt \& Proctor, 2015). Similar conclusions were reached in studies on the African continent that attributed people's low savings rates to low net worth, inadequate income, poor education, and poverty (Amu \& Amu, 2012; Issahaku, 2011). The conclusions from these studies show that income is positively related to savings, as individuals with higher income tend to have much more money to save.

Other studies, however, reached different conclusions asserting savings were a necessity across all income levels. The poor may be motivated to save to elevate 
their social status, for non-essential expenditures, and to build a buffer against unexpected changes in income or expenditure (Charles, Hurst, \& Roussanov, 2009). However, despite the relativity of income and savings levels across various income strata, all households and individuals can save.

\subsubsection{Corporate Governance}

Corporate governance broadly refers to rules and practices by which companies are managed. Empirical studies conducted on the association between governance and firm performance showed a positive relation between the two variables (Munisi \& Randoy, 2013; Sami, Wang, \& Zhou, 2011). Inadequacies in leadership, management and governance capacity were ranked the major cause for failures of co-operative societies (Agri-ProFocus Zambia, 2014; Mumanyi, 2014) whereas member apathy in decision-making forums led to poor governance of SACCOs (Hirschland, Jazayeri, \& Lee, 2008). Other studies reached contra conclusions that there was no association between governance and company performance (Fallatah \& Dickins, 2012).

\subsubsection{Government Regulation}

Regulation of SACCOs has the benefit of instilling discipline and good governance and is essential for wider reach and deep entrenchment in the economy (Hirschland et al., 2008) and for the protection of depositors, the entities themselves, and the wider financial sector (Khafagy, 2019). The responsibility to provide sound legal and regulatory frameworks that create an enabling environment for financial institutions to operate under simple supervision and monitoring parameters lay with governments (Vetrivel \& Kumarmangalam, 2010) especially in areas of consumer protection, legal recourse, payment systems, and branchless banking (FinMark Trust, 2013).

Governments, however, were cautioned to regulate to the extent that they would be able to adequately supervise, to fully understand what they needed to regulate and supervise and avoid excessive control and political interference (Department for International Development, DFID, 2010), because if miscarried, it becomes worse than no regulation at all. Co-operative societies still required government support without which they could be susceptible to exclusion from regional and global co-operative society movements and deny them the developmental benefits of such affiliations especially in training, capacity building, marketing, advocacy, supervision, and liquidity management (Hirschland et al, 2008).

\subsubsection{Economic Empowerment and Poverty Alleviation}

SACCOs play a very important role in the economic empowerment and poverty alleviation of populations, especially the rural poor (Waweru, 2011). Poverty implies a lack as well as denial of means and opportunities essential for providing material needs and comforts to members of society, which would allow them to maintain a minimum acceptable living standard as dictated by their society (Adekola \& Dokubo, 2017). Empowerment refers to the ability of people to un- 
derstand, control, and act in the environment that affects their personal, social, economic, and political arena with a view to improving their life situations (Golla, Malhotra, Nanda, \& Mehra, 2018). Thus, economic empowerment should occur when individuals and communities are enabled to have power and control and act effectively to change the economic well-being of their lives and their environment.

Access to financial services has been touted to improve the capacity of individuals to acquire productive assets for wealth creation and financial independence (Stenga, 2011). Evidently, community-based financial institutions have proved to empower people economically and lessen the prevalence of poverty, especially in rural communities (Ghaliba, Issam, \& Katsushi, 2014). However, some studies have argued that micro-credit is not the absolute means for poverty reduction and could negatively affect people's net worth leaving them more indebted and struggling financially (Roodman, 2009).

\section{Research Methodology}

\subsection{Research Hypothesis}

The research design for this study assumed a quantitative methodology using cross-sectional time-horizon. The research employed a questionnaire in the survey, assuming a deductive and descriptive approach in its design to address the research questions. This is because the research questions sought to understand the challenges that impede penetration of SACCOs in Zambia presently and therefore was addressing the "what" aspect of the inquiry. The research methodology and design were carefully chosen to achieve the objective of the study, which was to examine the challenges that have impeded the penetration of SACCOs in Zambia. Stemming from the research questions identified, the review of literature and the conceptual framework developed, the research tested the following hypotheses:

$\mathrm{H}_{0}$ 1: There is no relationship between awareness education and use of SACCOs.

$\mathrm{H}_{0}$ 2: There is no relationship between financial literacy and use of SACCOs.

$\mathrm{H}_{0}$ 3: There is no relationship between societal influence and use of SACCOs.

$\mathrm{H}_{0}$ 4: There is no relationship between gender and use of SACCOs.

$\mathrm{H}_{0}$ 5: There is no relationship between age and use of SACCOs.

$\mathrm{H}_{0}$ 6: There is no relationship between income level and use of SACCOs.

$\mathrm{H}_{0}$ 7: There is no relationship between corporate governance and use of SACCOs.

$\mathrm{H}_{0}$ 8: There is no relationship between government regulation and use of SACCOs.

\subsection{Population, Sampling Frame and Sample}

A study population can be simply referred to as the entirety of universe that a researcher wishes to base their investigation on. This study set-out to investigate 
a problem affecting Zambia as a whole, and therefore the intended population included all people in Zambia, who are adults and of legal age to personally engage in savings and investment programs. According to the latest voters' register held by the Electoral Commission of Zambia (ECZ), the population of adults eligible to vote and registered as voters as at 2016 was estimated at 6.7 million (ECZ, 2016).

Given the large and widely distributed population for the study, a sampling frame was drawn out in a three-stage multistage sampling technique which picked two provinces, and from each province two districts and finally eight constituencies from these four districts, selected using random sampling. The sampling frame for this study included 633,706 people in total. Seeing as the population was in excess of 10,000 members, this was considered a large population in research. Mugenda and Mugenda (2012) posited that where a research population is large, the recommended minimum sample size is 384 . This sample size is predicated on the assumption that the population is normally distributed, and the degree of confidence is $95 \%$, at a significance level of $5 \%$.

This minimum sample size for large population is derived from the formula below:

$$
n=Z^{2} * p *(1-p) / d^{2}
$$

where:

$n=$ Sample size for large population,

$Z=$ Normal distribution $Z$ value score, (1.96)

$p=$ Proportion of units in the sample size possessing the variables under study (usually set at $50 \%$ or 0.5 ),

$d=$ Precision or significance level which is 0.05 for the study.

Substituting the figures into the formula gives the following result:

$$
n=\frac{(1.96)^{2} *(0.5)(0.5)}{(0.05)^{2}}=384
$$

Therefore, the sample size for this study was 384 participants, at a confidence level of $95 \%$ and margin of error of $5 \%$. The sample was proportionately distributed between the adult population.

Table 1 gives a summary the sampling frame, and the sample size as detailed in the preceding paragraphs.

Following adoption of the quantitative methodology, the primary source of data collection was a questionnaire employing Likert scale and close-ended questions. The Likert scale has the advantage of presenting qualitative responses into quantifiable measures (ibid). The researcher designed the questionnaire using variables identified in the conceptual framework that captured all the elements addressing the objective of the study.

\subsection{Validity and Reliability of the Questionnaire}

The questionnaire was tested for validity and reliability using a pilot test on a 
Table 1. Sampling frame and sample size.

\begin{tabular}{|c|c|c|c|c|c|}
\hline Province & District & Constituency & Adult Population & $\%$ of Population & Sample \\
\hline & Chongwe & Chongwe & 71,095 & 11 & 43 \\
\hline \multirow[t]{4}{*}{ Lusaka } & & Kanyama & 136,198 & 21 & 83 \\
\hline & Lusaka & Kabwata & 100,404 & 16 & 61 \\
\hline & & Matero & 130,403 & 21 & 79 \\
\hline & Choma & Choma Central & 73,705 & 12 & 45 \\
\hline \multirow[t]{3}{*}{ Southern } & & Mbabala & 35,403 & 6 & 21 \\
\hline & Monze & Bweengwa & 28,581 & 5 & 17 \\
\hline & & Monze Central & 57,917 & 9 & 35 \\
\hline Total & & & 633,706 & 100 & 384 \\
\hline
\end{tabular}

Table 2. Cronbach alpha values for reliability test.

\begin{tabular}{ccc}
\hline Variable & Number of Items & Cronbach Alpha values \\
\hline Awareness Education & 18 & 0.911 \\
Financial Literacy & 12 & 0.794 \\
Societal Influence-Family and Peer & 7 & 0.979 \\
Demographics-Age and Gender & 12 & 0.811 \\
Income Level & 8 & 0.783 \\
Corporate Governance & 8 & 0.855 \\
Government Regulation & 3 & 0.710 \\
\hline
\end{tabular}

sample of 38 randomly selected participants who did not take part in the main survey. This sample is considered adequate as the rule of thumb requires one percent of the sample to constitute a pilot test, within the constraints of time, cost and effort required for the exercise (Creswell, 2014). Revisions were made appropriately to streamline the questionnaire for ease of understanding by people across different literacy levels. The reliability of the questionnaire was examined with the Cronbach's Alpha technique. Using PSPP statistical analysis, the reliability tests yielded Alphas of more than 0.7 and therefore, except for re-phrasing the questions, none were dropped from the questionnaire. Table 2 shows gives the Alpha values of the reliability test for all the variables under study.

\section{Data Analysis}

As this study adopted a quantitative methodology, data analysis employed both descriptive and inferential statistics. Completed questionnaires were edited for completeness, accuracy, and consistency in responses, and were coded. Each question was assigned a numerical value, which was fed into the PSPP statistical tool that was used in the data analysis. The study used descriptive statistics to 
summarize, describe, and organize the collected data. For inferential tests Correlation analysis using Pearson's R, was used to test existence and extent of relationships between the independent and the dependent variables. Regression analysis was done in order to determine the strength of the relationship between the independent and dependent variables while ANOVA test was also used in determining the strength of influence that the different independent variables taken together had on the dependent variable.

\section{Summary of Findings and Conclusions}

The survey targeted a sample of 384 respondents. Of these, 278 questionnaires were satisfactorily completed and were retained for analysis. This was a response rate of $72 \%$, which is a successful response rate and above the $50 \%$ considered adequate (Mugenda \& Mugenda, 2012). The authors stated that a response rate of $50 \%$ is adequate, $60 \%$ is good while a response rate of $70 \%$ and above is excellent.

\subsection{Awareness Education}

The study investigated the existence and strength of a relationship between awareness education and use of SACCOs in Zambia. Findings reveal that majority of people in Zambia (63\%), did not know what SACCOs were with only $37 \%$ indicating they knew about SACCOs as shown in Figure 4.

A further analysis reveals that of those who knew something about SACCOs, $61 \%$ were not aware of their existence anywhere around their vicinity with minority $31 \%$ indicating they were SACCO members. Majority of respondents were confusing SACCOs with village banking and ROSCAs cum table-banking and merry-go-round arrangements, which are informal, small groups of friends, and do not offer members a shareholding stake in them.

Linear regression results on the same variables reveal a significant association between awareness education and use of SACCOs represented by R Square 0.80 , implying that $80 \%$ of variation in use of SACCOs can be explained by awareness education. Similarly, Correlation analysis using Pearson's R shows that use of SACCOs is positively correlated with awareness education with significant correlation coefficient of 0.89 and p-value of 0.000 , depicted below:

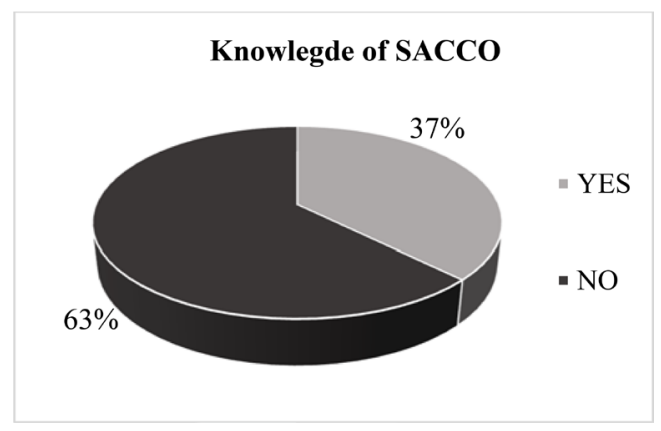

Figure 4. Respondents' awareness of SACCOs. 


$$
R(278)=0.89, p<0.05 .
$$

Study findings show that awareness education is statistically significant in explaining the extent of use of SACCOs and lead to the conclusion that lack of awareness about existence and essence of SACCOs has led to the low integration of SACCOs in Zambia. The results affirm the deduction that lack of awareness hampers development of SACCOs (Kifle, 2012), and financial education is a key constituent in savings decisions (Turnham, 2010; Adekola \& Dokubo, 2017). The findings uphold the Institutional Theory of Savings which gives information as one of the five paradigms that shape an individual's savings and wealth creation. Similarly, the findings underpin the fifth Co-operative Principle which emphasizes the centrality of the co-operative education, training and information in development, nature, and benefits of the co-operatives (ICA, 2018). These findings suggest that the null hypothesis be rejected, and the alternative hypothesis be accepted which indicates that there is a relationship between awareness education and use of SACCOs.

\subsection{Financial Literacy}

Descriptive statistics indicate that overall, people wanted to analyse and assess the benefits and risks of financial ventures before they would commit to engaging in them. A majority $69 \%$ agreed that they always sought enough information before they decided on savings or investments, while $86 \%$ would only save where they were sure it was safe to do so. A mean $63 \%$ agreed that financial literacy helped improve people's capability to manage their finances through improved decision making. Regression analysis results reveal a strong relationship between financial literacy and use of SACCOs, with an R Square of 0.53 implying that financial literacy explains $53 \%$ of the variation in use of SACCOs. Results from the Pearson correlation are aligned with the regression test results, indicating a high and positive. 73 correlation between the variables at a significance level of 0.000 as depicted below:

$$
r(278)=0.73, p<0.05
$$

Table 3 contains the results of the Correlation test.

The findings are consistent with earlier empirical studies which confound the

Table 3. Financial literacy and use of SACCOs.

\begin{tabular}{cccc}
\hline Variable & & Use of SACCOs & Financial Literacy \\
\hline Use of SACCOs & Pearson Correlation & 1.00 & 0.73 \\
& Sig. (2-tailed) & & 0.000 \\
$\mathrm{~N}$ & 278 & 278 \\
\hline Financial Literacy & Pearson Correlation & 0.73 & 1.00 \\
& Sig. (2-tailed) & 0.000 & 278 \\
\hline
\end{tabular}


importance of financial literacy in better financial decisions especially in the wake of sophisticated financial products and increasing customers' needs (Lusardi \& Mitchell, 2014; Nye, Pete, \& Cinnamon, 2013). The results resonate with the principle of the Model of Financial Literacy which advocates that an individual who is financially knowledgeable has sharper financial skills and ability to make better savings and economic decisions.

The implication, therefore, is that for SACCOs to be well integrated in the Zambian economy, full information regarding the nature and operations, and in particular the risks and benefits of SACCOs should be readily available in a manner that is well understood and relevant for the intended audience, recognizing the diversity of the Zambian population along several dimensions including rural/urban, demographics and economic status of the population. Going by the findings, the null hypothesis is thus rejected and the alternative one adopted stating that there is a relationship between financial literacy and use of SACCOs.

\subsection{Societal Influence}

Findings reveal that majority of people in Zambia would want to save and invest in institutions and products where family or peers were also engaged in. Results in Table 4 indicate that $71 \%$ of respondents agreed that they saved and invested where their family members also saved and invested, and further $75 \%$ agreed that they would consider joining a SACCO if their family were members too. The study further revealed that peers had a significant influence in people's financial decisions.

Regression analysis tests reveal a goodness-of-fit between the two variables, with an $\mathrm{R}$ Square of 0.56 meaning that $56 \%$ of variations in use of SACCOs could be explained by changes in societal influence. Pearson's correlation test indicate that societal influence is positively correlated with use of SACCOs, with a strong $75 \%$ positive correlation and significance level of 0.000 , depicted as:

$$
r(278)=0.75, p<0.05
$$

These study findings show that societal influence comprising family and peers

Table 4. Societal Influence and Use of SACCOs.

\begin{tabular}{|c|c|c|c|c|}
\hline \multirow{2}{*}{ Statement } & \multicolumn{3}{|c|}{ Strongly Agree Disagree } & \multirow{2}{*}{$\begin{array}{c}\text { Strongly } \\
\text { Disagree \% }\end{array}$} \\
\hline & Agree \% & $\%$ & $\%$ & \\
\hline I invest and save where my family members also save or invest & 38 & 33 & 17 & 11 \\
\hline I would consider joining a SACCO if my family were members too & 39 & 36 & 15 & 10 \\
\hline My family encourages members to save and invest from an early age & 16 & 18 & 40 & 26 \\
\hline $\begin{array}{l}\text { I listen to my friends' advice on finances, and this influences the financial } \\
\text { decisions I make }\end{array}$ & 43 & 35 & 14 & 8 \\
\hline I would join a savings society if my friends were members & 41 & 32 & 14 & 13 \\
\hline Mean & 36 & 31 & 20 & 14 \\
\hline
\end{tabular}


was statistically significant in explaining the extent of use and membership in SACCOs. The link between societal influences and savings behaviours affirms findings by earlier studies (Karunaanithy et al., 2017; Brown \& Taylor, 2016; Cronqvist \& Siegel, 2015). Consistent with the Social Psychological Theory, the findings uphold the main thrust of the theory that society could model individuals and had a key influence on human behaviour. This implies that in Zambia, family and social ties play a major role in shaping behaviours of individuals, including financial behaviours and therefore, an important factor to consider in the strategy to revive SACCOs. Consequently, the null hypothesis is rejected and the alternate hypothesis, which asserts that there is a relationship between societal influence and use of SACCOs is upheld.

\subsection{Gender}

Descriptive results indicate that more females had savings than men, $45 \%$ and $34 \%$ respectively, and that of the $31 \%$ respondents who were members of a SACCO, $21 \%$ were female. Results from Pearson's correlation reveal a marginally significant and weak 0.17 correlation between the two variables on the negative side. Linear regression analysis indicates that only $3 \%$ of variation in use of SACCOs could be explained by the gender variable, represented by the R Square of 0.03 .

The findings echo earlier studies whose conclusions were equally at variance. Mahdzan and Tabiani (2013), averred that gender had a considerable influence on savings behaviours, with women saving more than men. On the contrary, Bokemeiner, Loveridge and Whitaker (2013), asserted that there were no significant differences in savings patterns across gender while still others found that women had a lower risk tolerance than men (Majurin, 2012). However, given the weak correlation between the variables, no conclusive argument can be made for the relationship between gender and use of SACCOs. Consequently, the null hypothesis is adopted.

\subsection{Age}

The study results from the age variable as a determinant for use of SACCOs indicate that out of the 278 respondents, $79 \%$ engaged in savings generally while those aged between 31 and 40 had the highest savings at $31 \%$ of the total. Table 5 shows the savings pattern by age group.

Table 5. Savings maintenance by age.

\begin{tabular}{cccccccc}
\hline \multirow{2}{*}{ Maintain Savings } & \multicolumn{7}{c}{ Age of Respondents } \\
\cline { 2 - 6 } & $\mathbf{1 8 - 3 0}$ & $\mathbf{3 1 - 4 0}$ & $\mathbf{4 1 - 5 0}$ & $\mathbf{5 1 - 6 0}$ & Above 60 & \\
\hline Yes & $14 \%$ & $31 \%$ & $14 \%$ & $15 \%$ & $5 \%$ & $79 \%$ \\
No & $11 \%$ & $10 \%$ & - & - & - & $21 \%$ \\
Total & $25 \%$ & $41 \%$ & $14 \%$ & $15 \%$ & $5 \%$ & $100 \%$ \\
\hline
\end{tabular}


Similarly, of the respondents who were SACCO members, $52 \%$ of them were aged between 31 and 40 years. Respondents agreed in their majority, 68\%, that people could save regardless of age. These findings support the principle of Lifecycle of Savings theory which gives a pattern of savings behaviour across different age groups, with savings low at young adult age, peaking in middle age before declining at retirement age. Similarly, the results are aligned with findings that established a link between age and saving (Chowa et al., 2012; Bover et al., 2013). This implies that for SACCOs to get integrated in the economy, sensitization and membership drive efforts should start with young adults to ensure long-term continuity of membership.

However, results from Pearson's correlation indicate a marginally significant albeit weak positive correlation of 0.19 between the two variables. Regression analysis further resulted in an $\mathrm{R}$ Square of 0.04 implying that only $4 \%$ of variations in use of SACCOs could be explained by the age variable. Given the weak correlation between age and use of SACCOs, no conclusive argument can be made for the relationship between the variables and therefore, the hypothesis is upheld.

\subsection{Income Level}

The study findings showing the income distribution of the 278 respondents reveal that majority are in the lower income bracket, with $68 \%$ earning a monthly salary of Zambia Kwacha (ZMK) 10,000 (equivalent to US\$900¹) and below while only $6 \%$ earn in excess of ZMK 30,000 per month. Figure 5 shows the income distribution among the survey respondents.

Of these, all respondents earning above ZMK 10,000 had savings while the $27 \%$ who did not maintain savings were in the below ZMK 10,000 per month earnings bracket. Further analysis indicates that $68 \%$ of respondents agreed that their level of income was not enough to save, $72 \%$ citing too many responsibilities hindering their ability to save, while those who agreed that saving was possible

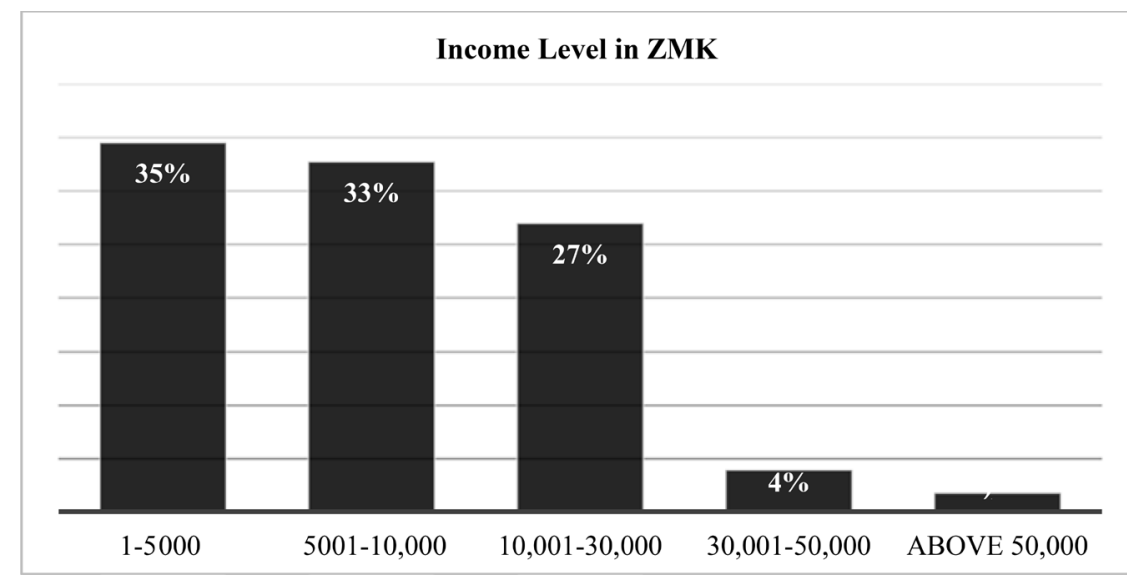

Figure 5. Respondents' income distribution (in ZMK).

${ }^{1}$ The average exchange rate at the time of the research was $1 \mathrm{USD}=9 \mathrm{ZMK}$. 
regardless of one's income are a minority $32 \%$. These findings affirm previous studies that asserted that income is positively related to savings, with higher income individuals saving more (Amu \& Amu, 2012; Gjertson, 2016; DeNavas-Walt \& Proctor, 2015). Also, these findings affirm the provisions of the Permanent Income Hypothesis theory which argues that savings are only possible if people have positive transitory income.

On the contrary, SACCO membership among income groups shows a decreasing trend as savings increase. Results of Pearson's correlation test reveal a statistically significant but negative correlation of -0.36 between income level and use of SACCOs and a p-value of 0.000. A scatter plot derived from the data equally reveals that there is a negative relationship between the two variables. This is depicted in the negatively sloping trendline on the scatterplot. Figure 6 shows the scatter plot of income levels and use of SACCOs.

The results therefore imply that higher income earners do not consider SACCOs as a priority vehicle for their savings while affirming conclusions by Charles et al. (2009), that even the poor could save. The findings are quite significant in explaining the low integration of SACCOs in Zambia. Low-income earners assume that they do not have enough to save while high income earners do not think belonging to SACCO can bring about any additional benefits than they would get from a conventional bank. Awareness programs can therefore be tailored to reverse the current trend and perceptions so that SACCOs can flourish across all income strata.

Given the statistically significant association between the two variables, the null hypothesis is rejected and the alternative, which indicates that there is a relationship between income level and use of SACCOs is adopted.

\subsection{Corporate Governance}

Results from descriptive statistics show evidence that people are increasingly demanding proper policies and procedures to govern institutions that manage

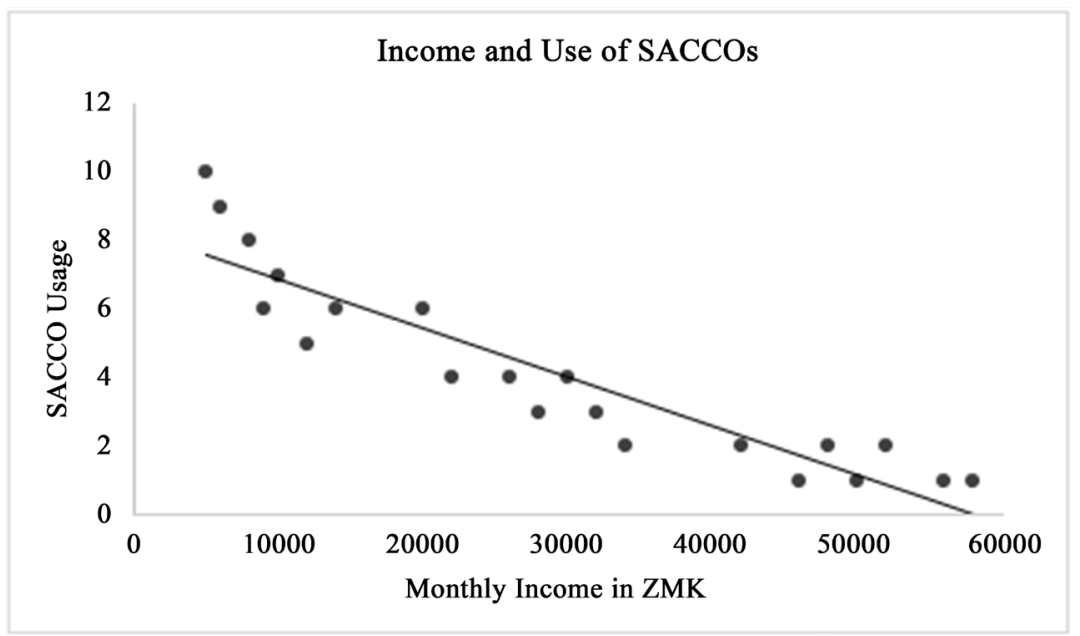

Figure 6. Respondents income and use of SACCOs. 
people funds, as well as quality and well-qualified people of integrity in their leaders. Majority of respondents, $83 \%$, agreed that organization should have proper policies and procedures to govern their operations and $77 \%$ majority agreed that internal politics negatively affected the survival of organizations. A further $86 \%$ agreed that good leadership was key to survival of organizations with only $34 \%$ indicating that they would choose a leader based purely on their relationship with the person.

Linear regression results evidence the goodness-of-fit between corporate governance and use of SACCOs with an R Square of 0.52. Further inferential statistics from Pearson's correlation reveal a high positive correlation of 0.72 between the two variables at a $\mathrm{p}$-value of 0.000 .

$$
r(278)=0.72, p<0.05
$$

Table 6 contains the results of the correlation test.

These findings are in line with previous empirical studies citing good governance as necessary for survival of co-operatives (Agri-ProFocus Zambia, 2014; Mumanyi, 2014; Munisi \& Randoy, 2013). This implies that if SACCOs were to assume national, well-managed, first-point-of-call institutions for savings among the Zambian people, good leadership and governance practices must be present. In line with the principle of the Agency Theory, although leaders in SACCOs are members as well, separation of ownership and control in principal-agent relationships is very important. Going by the results, the null hypothesis is thus rejected and the alternative one adopted stating that there is a relationship between corporate governance and use of SACCOs.

\subsection{Government Regulation}

Study results show that $91 \%$ of respondents were not aware of any regulation governing SACCOs in Zambia. The study further revealed that $78 \%$ expressed that the government should enact laws to regulate community-based financial institutions while only $23 \%$ thought the existing laws were adequate. Although $82 \%$ still agreed that government support was needed for survival of these institution, $61 \%$ supported self-regulation. Table 7 shows the descriptive statistics on statements on government regulation.

Table 6. Corporate governance and use of SACCOs.

\begin{tabular}{cccc}
\hline Variables & & Corporate Governance & Use of SACCOs \\
\hline Corporate Governance & Pearson Correlation & 1.00 & 0.72 \\
& Sig. (2-tailed) & & 0.000 \\
& $\mathrm{~N}$ & 278 & 278 \\
Use of SACCOs & Pearson Correlation & 0.72 & 1.00 \\
& Sig. (2-tailed) & 0.000 & \\
& $\mathrm{~N}$ & 278 & 278 \\
\hline
\end{tabular}


Regression results obtained show goodness-of-fit between government regulation and use of SACCOs with an R Square of 0.57. Correlation analysis between government regulation and use of SACCOs indicates that the variables are positively correlated with a strong correlation coefficient of 0.76 and p-value of 0.000 depicted as:

$$
r(278)=0.76, p<0.05
$$

The results of the correlation test between government regulation and use of SACCOs are shown in Table 8.

The results echo previous studies which argue for adequate government regulation (FinMark Trust, 2013; Vetrivel \& Kumarmangalam, 2010; Hirschland et al., 2008), albeit devoid of political interference and excessive control (DFID, 2010). This implies that for SACCOs in Zambia, adequate regulation would create the much-needed confidence among members and ensure a deeper integration in the economy. Government regulation should therefore not be mis-carried nor should it stifle the SACCOs. Rather, regulation should allow for autonomy without government interference but within the confines of the law.

Given the findings from the study that show a positive and significant link between the two variables, the null hypothesis is rejected, and the alternative hypothesis is adopted which is that there is a relationship between government regulation and use of SACCOs.

Table 7. Regulation and supervision and use of SACCOs.

\begin{tabular}{|c|c|c|c|c|}
\hline \multirow{2}{*}{ Statement } & \multicolumn{3}{|c|}{ Strongly Agree Disagree } & \multirow{2}{*}{$\begin{array}{c}\text { Strongly } \\
\text { Disagree \% }\end{array}$} \\
\hline & Agree \% & $\%$ & $\%$ & \\
\hline The government must be seen to support community-based institutions & 50 & 32 & 13 & 6 \\
\hline Community financial institutions should be left to regulate themselves & 33 & 28 & 21 & 18 \\
\hline $\begin{array}{l}\text { Laws and regulations must be enacted to govern operations of community } \\
\text { based financial institutions }\end{array}$ & 40 & 38 & 17 & 5 \\
\hline $\begin{array}{l}\text { Improving lives of communities does not necessarily require government } \\
\text { involvement }\end{array}$ & 24 & 20 & 32 & 24 \\
\hline The current laws governing co-operative societies in Zambia are adequate & 9 & 14 & 33 & 44 \\
\hline Mean & 31 & 26 & 23 & 19 \\
\hline
\end{tabular}

Table 8. Government regulation and use of SACCOs.

\begin{tabular}{cccc}
\hline Variable & & Government Regulation & Use of SACCOs \\
\hline Government Regulation & Pearson Correlation & 1.00 & 0.76 \\
& Sig. (2-tailed) & & 0.000 \\
& $\mathrm{~N}$ & 278 & 278 \\
Use of SACCOs & Pearson Correlation & 0.76 & 1.00 \\
& Sig. (2-tailed) & 0.000 & 278 \\
\hline
\end{tabular}




\subsection{Overall Model Analysis}

The independent variables taken together indicate a goodness-of-fit for the linear regression with the dependent variable. With an R Square of.94 meaning that the combined variations in independent variables: awareness education, financial literacy, societal influence, age, gender, income level, corporate governance, and government regulation, explain $94 \%$ variations in the independent variable, use of SACCOs. ANOVA results likewise indicate that the independent variables in the model were statistically significant in jointly explaining use of SACCOs with an F statistic of 506, and a p-value of 0.000. The statistical significance between the independent and dependent variables is shown as follows:

$$
F(8,269)=505.92, p<0.05
$$

Table 9 presents the ANOVA results of the overall model.

Table 9. ANOVA-overall model summary.

\begin{tabular}{cccccc}
\hline & Sum of Squares & df & Mean Square & F & Sig. \\
\hline Regression & 55.33 & 8 & 6.92 & 505.92 & 0.000 \\
Residual & 3.68 & 269 & 0.01 & & \\
Total & 59.01 & 277 & & & \\
\hline
\end{tabular}

\section{Recommendations}

Arising from the results of the study, it is recommended that an SACCO strategy should be developed at the national level, as an economic policy document that should apply countrywide. The relevant authorities in Zambia under whose mandate SACCOs fall should create awareness programs targeting all age groups comprising both men and women in rural and urban areas alike, across different sectors. The mandate of poverty alleviation and economic empowerment cuts across these demographic and social divides. Deliberate efforts aimed at attracting young people to join SACCOs should be undertaken to ensure posterity as well as long-term survival of SACCOs.

Sensitization should emphasize the poverty alleviation and economic benefits of SACCOs as well as the unique feature of ownership by members to distinguish SACCOs from other institutions, which do not make one an owner. Information should be made readily available and accessible in a manner that is easy to understand by all, to both existing and prospective members, detailing the risks and benefits of SACCOs. This is especially important given that people generally perceive financial services as too expensive and complicated.

Family and peers play a significant role in influencing people's savings behaviours. It is recommended that efforts to popularise SACCOs in the country should target families. Furthermore, it is important to identify autonomous groupings where peer influence is high, especially employment, business affiliations, learning institutions, churches, and other religious groups. Individuals 
who command respect and influence in respective communities should also be identified and empowered to lead the sensitization strategy. This, however, should be done with caution to avoid abuse of power at the expense of the people. When the leaders in these societal settings buy into the idea, there is a high chance that others will follow, too.

Being owner-managed institutions, some SACCOs may not have members with the requisite skills or competencies to run the entities. It is recommended that the proposed SACCO strategy should offer support to mentor leaders and put mechanism to monitor the operations of SACCOs to ensure proper adherence to standard operating policies and procedures and curtail abuse of authority. Bench marking with countries within the region and beyond whose SACCO sector is thriving should be done. The study further recommends that the Central Bank (Bank of Zambia) should designate a specific bank as the banker for SACCOs for proper monitoring and supervision of SACCO operations. Banks should be encouraged to offer complementary rather than competitive services to SACCO members. They can do this by training SACCO leaders in sound financial management practices.

It is further recommended that the government should give due prominence to SACCOs as a key sector of the economy aimed at alleviating poverty from among its citizens. Proper laws and regulations should be enacted to govern the operations of SACCOs, which should be enforceable and capable of instilling confidence and discipline in the sector. Therefore, without interfering in the autonomy of, or impose laws which are retrogressive and defeat the mandate of SACCOs, the government should regulate the SACCOs in Zambia while desisting from political interference, manipulation, and control, that have been associated with these entities in the past. Furthermore, the apex bodies for SACCOs and co-operatives must be empowered to effectively carry out their oversight roles. Membership to such a body must be made mandatory for all SACCOs and co-operatives in general for proper monitoring of numbers, membership, assets, and other relevant statistics.

The above recommendations have the potential to revive the SACCO and the wider co-operative movement in Zambia as well as set the platform and a basis for follow-up studies on co-operative societies in Zambia.

\section{Conflicts of Interest}

The author declares no conflicts of interest regarding the publication of this paper.

\section{References}

Adekola, G., \& Dokubo, C. (2017). Co-Operative Societies and Poverty Reduction among Members for Community Development in Rivers State, Nigeria. European Scientific Journal, 13, 250-259.

African Confederation of Co-Operative Savings and Credit Associations, ACCOSCA 
(2018). About Us. https://accosca.org/about-us/

Agri-ProFocus Zambia (2014). A Market Study on Microfinance Services in Zambia. Lusaka, Zambia: APF.

Allport, F. H. (1924). Response to Social Stimulation in the Group. In F. H. Allport (Ed.), Social Psychology (pp. 260-291). Hillsdale, NJ: Erlbaum.

Altunc, O. F., \& Aydin, C. (2014). An Estimation of the Consumption Function under the Permanent Income Hypothesis: The Case of D-8 Countries. Journal of Economic Cooperation \& Development, 35, 29-42.

Amu, M. E. K., \& Amu, E. K. (2012). Savings Behaviour in Ghana: A Study of Rural Households in the Ho Municipality of Volta Region. Journal of Social Sciences Research, 1, 54-61.

Bandura, A., Ross, D., \& Ross, S. A. (1963). Vicarious Reinforcement and Imitative Learning. The Journal of Abnormal and Social Psychology, 67, 601-607.

https://doi.org/10.1037/h0045550

Banerjee, A., Meng, X., \& Qian, N. (2010). The Lifecycle Model and Household Savings. Micro Evidence from Urban China. Working Paper, New Haven, CT: Yale University.

Beckmann, E. (2013). Financial Literacy and Household Savings in Romania. Numeracy, 6, Article 9. https://doi.org/10.5038/1936-4660.6.2.9

Bertea, P. E., \& Zait, A. (2014). Financial Literacy-Conceptual Definition and Proposed Approach for a Measurement Instrument. Journal of Accounting and Management, 4, $37-42$.

Bokemeiner, J. L., Loveridge, S., \& Whitaker, E. A. (2013). Interactional Associations of Gender on Savings Behavior: Showing Gender's Continued Influence on Economic Action. Journal of Family and Economic Issues, 34, 105-119.

https://doi.org/10.1007/s10834-012-9307-2

Bover, O., Casado, J., Costa, S., Du Caju, P., McCarthy, I., Sierminska, E., Tzamourani, P., Villanueva, E., \& Zavadil, T. (2013). The Distribution of Debt across Euro Area Countries: The Role of Individual Characteristics, Institutions and Credit Conditions. ECB Working Paper No. 1639. https://doi.org/10.2139/ssrn.2369898

Brown, S., \& Taylor, K. (2016). Early Influences on Saving Behaviour: Analysis of British Panel Data. Journal of Banking and Finance, 62, 1-14.

https://doi.org/10.1016/j.jbankfin.2015.09.011

Chaddad, F., \& Valentinov, V. (2016). Agency Costs and Organizational Architecture of Large Corporate Farms: Evidence from Brazil. International Food and Agribusiness Management Review, 20, 201-220. https://doi.org/10.22434/IFAMR2016.0009

Charles, K. K., Hurst, E., \& Roussanov, N. (2009). Conspicuous Consumption and Race. The Quarterly Journal of Economics, 124, 425-467. https://doi.org/10.1162/qjec.2009.124.2.425

Chen, M. K. (2013). The Effect of Language on Economic Behavior: Evidence from Savings Rates, Health Behaviors, and Retirement Assets. American Economic Review, 103, 690-731. https://doi.org/10.1257/aer.103.2.690

Chowa, G. A. N., Masa, R. D., \& Ansong, D. (2012). Determinants of Saving among Low-Income Individuals in Rural Uganda: Evidence from East Africa. Advances in Applied Sociology, 2, 280-291. https://doi.org/10.4236/aasoci.2012.24037

Chung-Yan, G. A., Krieger, M. A., \& Towson, M. J. (2017). Social Psychology Theory. Thousand Oaks, CA: Sage Publications Inc.

Corporation for Enterprise Development (2016). 2016 Assets and Opportunity Scorecard. 
https://community-wealth.org/content/cfed-assets-and-opportunity-scorecard

Creswell, J. W. (2014). Research Design: Qualitative, Quantitative and Mixed Methods Approaches (4th ed.). Thousand Oaks, CA: Sage.

Cronqvist, H., \& Siegel, S. (2015). The Origins of Savings Behaviour. Journal of Political Economy, 123, 123-169. https://doi.org/10.1086/679284

Curley, J., Ssewamala, F., \& Sherraden, M. (2009). Institutions and Savings in Low-Income Households. The Journal of Sociology \& Social Welfare, 36, Article 2.

DeNavas-Walt, C., \& Proctor, B. (2015). Income and Poverty in the United States: 2014. https://www.census.gov/content/dam/Census/library/publications/2015/demo/p60-252 .pdf

Department for International Development (2010). Working with Co-Operatives for Poverty Reduction. Briefing Note.

https://coop-web-assets.s3-eu-west-1.amazonaws.com/uploads/2010/08/CooperativesBriefing-Note.pdf

Electoral Commission of Zambia, ECZ (2016). National Totals. 2016 Presidential Elections Held on 11 August 2016. https://www.eisa.org/wep/zam2016results.htm

Fallatah, Y., \& Dickins, D. (2012). Corporate Governance and Firm Performance and Value in Saudi Arabia. African Journal of Business Management, 6, 10025-10034.

https://doi.org/10.5897/AJBM12.008

FinMark Trust (2013). The Status of Agricultural and Rural Financial Services in Southern Africa 2011. Zambia Country Report.

FinScope (2015). FSD Zambia: Expanding Financial Inclusion. Bank of Zambia.

Friedman, M. (1957). The Permanent Income Hypothesis. A Theory of the Consumption Function. Princeton, NJ: Princeton University Press. https://doi.org/10.1515/9780691188485-005

Gathergood, J. (2012). Self-Control, Financial Literacy and Consumer Over-Indebtedness. Journal of Economic Psychology, 33, 590-602.

https://doi.org/10.1016/j.joep.2011.11.006

Ghaliba, A. K., Issam, M., \& Katsushi, S. I. (2014). Microfinance and Household Poverty Reduction: Empirical Evidence from Rural Pakistan. Oxford Development Studies, 43, 84-104. https://doi.org/10.1080/13600818.2014.980228

Gjertson, L. (2016). Emergency Saving and Household Hardship. Journal of Family and Economic Issues, 37, 1-17. https://doi.org/10.1007/s10834-014-9434-Z

Golla, A., Malhotra, A., Nanda, P., \& Mehra, R. (2018). Understanding and Measuring Women's Economic Empowerment. International Centre for Research on Women. https://www.icrw.org/publications/understanding-and-measuring-womens-economicempowerment

Hardy, B., \& Ziliak, J. P. (2014). Decomposing Trends in Income Volatility: The "Wild Ride" at the Top and Bottom. Economic Inquiry, 52, 459-476. https://doi.org/10.1111/ecin.12044

Harnisch, T. L. (2010). Boosting Financial Literacy in America: A Role for State Colleges and Universities. In Perspectives. Washington DC: American Association of State Colleges and Universities.

Haslinda, A., \& Valentine, B. (2009). Fundamental and Ethics Theories of Corporate Governance. Middle Eastern Finance and Economics, 4, 88-96.

Hirschland, M., Jazayeri, A., \& Lee, N. (2008). Financial Services in Remote Rural Areas. What We Know about Member-Owned Institutions. Coady International Institute. 
http://coady.stfx.ca

Horioka, C. Y. (2016). Are the Japanese Unique? Evidence from Household Saving and Bequest Behavior. The Institute of Social and Economic Research Osaka University, Discussion Paper No. 973. https://doi.org/10.2139/ssrn.2788379

Hung, A. A., Parker, A. M., \& Yoong, J. K. (2009). Defining and Measuring Financial Literacy. https://doi.org/10.2139/ssrn.1498674 https://www.rand.org/content/dam/rand/pubs/working papers/2009/RAND WR708.p df

International Co-Operative Alliance, ICA (2018). What Is a Co-Operative? https://ica.coop/en/whats-co-op/co-operative-identity-values-principles

Issahaku, H. (2011). Determinants of Household Savings and Investment in Deprived District Capitals in Ghana: A Case Study of Nadowli in the Upper West Region of Ghana. Continental Journal of Social Sciences, 4, 1-12.

Karunaanithy, K., Karunanithy, M., \& Santhirasekaram, S. (2017). Understanding and Responding to Youth Savings Behaviour: Evidence from Undergraduates in the War-Torn Regions of Sri Lanka. International Journal of Research and Development, 2, 124-131.

Khafagy, A. (2019). The Economics of Financial Co-Operatives: Income Distribution, Political Economy and Regulation. New York: Routledge. https://doi.org/10.4324/9780429342196

Kifle, T. S. (2012). The Impact of Savings and Credit Co-Operatives in Ofla Wereda Tigray Region of Ethiopia. European Journal of Business and Management, 4, 78-91.

Lolojih, P. K. (2009). Bearing the Brunt of a Liberalized Economy: A Performance Review of the Co-Operative Movement in Zambia. Coop AFRICA Working Paper No. 16.

Lopez, S., Lopez, U., \& Larraga, L. (2009). Innovation and Industrial Co-Operatives: Special Features and Potential of the Mondragon Model. International Journal of Technology Management \& Sustainable Development, 8, 39-56. https://doi.org/10.1386/ijtm.8.1.39 1

Lusardi, A., \& Mitchell, O. S. (2014). The Economic Importance of Financial Literacy: Theory and Evidence. Journal of Economic Literature, 52, 5-44.

https://doi.org/10.1257/jel.52.1.5

Lusardi, A., Mitchell, S. L., \& Curto, V. (2010). Financial Literacy among the Young. Journal of Consumer Affairs, 44, 358-380. https://doi.org/10.1111/j.1745-6606.2010.01173.x

Mahdzan, N. S., \& Tabiani, S. (2013). The Impact of Financial Literacy on Individual Savings. An Exploratory Study in the Malaysian Context. Transformations in Business and economics, 12, $41-55$.

Majurin, E. (2012). How Women Fare in East African Co-Operatives: The Case of Kenya, Tanzania, and Uganda. Dar es Salaam: International Labour Office, ILO.

Mayo, E. (2017). A Short History of Co-Operation and Mutuality. London: Co-Operatives UK.

McKillop, D., \& Wilson, J. O. (2011). Credit Unions: A Theoretical and Empirical Overview. Financial Markets, Institutions \& Instruments, 20, 79-123. https://doi.org/10.1111/j.1468-0416.2011.00166.x

Modigliani, F., \& Brumberg, R. H. (1954). Utility Analysis and the Consumption Function: An Interpretation of Cross-Section Data. In K. K. Kurihara (Ed.), Post-Keynesian Economics (pp. 388-436). New Brunswick, NJ: Rutgers University Press. 
Mottola, G. R. (2013). In Our Best Interest: Women, Financial Literacy, and Credit Card Behavior. Numeracy, 6, Article 4. https://doi.org/10.5038/1936-4660.6.2.4

Mugenda, A. G., \& Mugenda, O. M. (2012). Research Methods Dictionary. Nairobi: Kenya Arts Press.

Mumanyi, E. A. L. (2014). Challenges and Opportunities Facing SACCOs in the Current Devolved System of Government of Kenya: A Case Study of Mombasa County. International Journal of Social Sciences and Entrepreneurship, 1, 288-314.

Munisi, C., \& Randoy, T. (2013). Corporate Governance and Company Performance across Sub-Saharan African Countries. Journal of Economics and Business, 70, 92-110. https://doi.org/10.1016/j.jeconbus.2013.08.003

Mwakajumilo, S. L. (2011). The Role of Informal Microfinance Institutions in Saving Mobilization, Investment and Poverty Reduction: A Case of Savings and Credit Co-Operative Societies (SACCOS) in Tanzania from 1961-2008. PhD Thesis, Turks and Caicos Islands: St. Clement University.

Nye, K., Pete, W., \& Cinnamon, H. (2013). Personal Financial Behavior: The Influence of Quantitative Literacy and Material Values. Numeracy, 6, 23-26.

https://doi.org/10.5038/1936-4660.6.1.3

Obayelu, O. A. (2012). Saving Behavior of Rural Households in Kwara State, Nigeria. African Journal of Basic \& Applied Sciences, 4, 115-123.

https://doi.org/10.2139/ssrn.1999413

Otto, A. (2012). Saving in Childhood and Adolescence: Insights from Developmental Psychology. CSD Working Paper 12-20, St. Louis, MO: Washington University, Center for Social Development.

Pettinger, T. (2017). Life-Cycle Hypothesis. Economics Help. https://www.economicshelp.org/blog/27080/concepts/life-cycle-hypothesis/

President's Advisory Council on Financial Literacy (2008). 2008 Annual Report to the President.

https://www.treasury.gov/about/organizational-structure/offices/Domestic-Finance/Do cuments/PACFL Draft-AR-0109.pdf

Roodman, D. (2009). What Do We Really Know about Microfinance's Impact? https://www.findevgateway.org/case-study/2009/08/what-do-we-really-know-about-mi crofinance-impact

Sami, H., Wang, J., \& Zhou, H. (2011). Corporate Governance and Operating Performance of Chinese Listed Firms. Journal of International Accounting, Auditing and Taxation, 20, 106-114. https://doi.org/10.1016/j.intaccaudtax.2011.06.005

Sherraden, M. (1991). Assets and the Poor. Armonk, NY: M. E. Sharpe.

Shields, P., \& Rangarajan, N. (2013). A Playbook for Research Methods. Integrating Conceptual Frameworks and Project Management. Stillwater, OK: New Forums Press.

Stenga, J. E. (2011). Provision of MFI Services to Poor Households: Summary of Case Study on Demand and Challenges Facing Saving Products in Tajikistan Microfinance Institutions. European Micro Finance Platform 6th University Meets Microfinance Workshop, Groningen: University of Groningen.

Tajfel, H., Billig, M. G., Bundy, R. P., \& Flament, C. (1971). Social Categorization and Intergroup Behavior. European Journal of Social Psychology, 1, 149-178.

https://doi.org/10.1002/ejsp.2420010202

Turnham, J. (2010). Attitudes to Savings and Financial Education among Low-Income Populations: Findings from the Financial Literacy Focus Groups. Working Paper WP 
10-7, Madison, WI: Center for Financial Security, University of Wisconsin-Madison.

United Nations Development Programme, UNDP (2018). Human Development Reports. http://hdr.undp.org/en/countries/profiles/ZMB

Vera, M. A., Ugedo, M., \& Lario, N. (2010). Agency and Property Rights Theories in Agricultural Co-Operatives: Evidence from Spain. Spanish Journal of Agricultural Research, 8, 908-924. https://doi.org/10.5424/sjar/2010084-1384

Vetrivel, S. C., \& Kumarmangalam, C. (2010). Role of Microfinance Institutions in Rural Development. International Journal of Information Technology and Knowledge Management, 2, 435-441.

Wachira, M. I., \& Kihiu, E. N. (2012). Impact of Financial Literacy on Access to Financial Services in Kenya. International Journal of Business and Social Science, 3, 42-50.

Waweru, K. M. (2011). An Investigation into the Cash Balance Management Challenges in Saccos in Nakuru County, Kenya. Journal of Research in International Business and Management, 1, 130-135.

Webley, P., \& Nyhus, E. (2012). Economic Socialization, Saving, and Assets in European Young Adults. CSD Working Paper 12-01, St. Louis, MO: Washington University, Center for Social Development.

World Bank (2018). Poverty and Shared Prosperity 2018: Piecing Together the Poverty Puzzle. Overview Booklet. Washington DC: World Bank.

World Council of Credit Unions, WOCCU (2018). Statistical Reports. https://www.woccu.org/documents/2018 Statistical Report WOCCU 